\title{
The shallow bond: the profit motive figuring into Virginia Woolf's feminist message
}

\author{
Dr. Mariem Khmiri \\ The Higher Institute of Applied Studies in Humanities of Sbeitla, University of Kairouan, Tunisia \\ merriemkhmiri@hotmail.com \\ Received: 08 Apr 2021; Received in revised form: 29 May 2021; Accepted: 10 Jun 2021 \\ (C)2021 The Author(s). Published by TheShillonga. This is an open access article under the CC BY license \\ (https://creativecommons.org/licenses/by/4.0/)
}

\begin{abstract}
Woolf's vocabulary of feminist emancipation was the vector of her migration towards the genre of the novel. For all the vindictiveness it bears against gender inequality, exploring feminism as potential (i.e., as future-oriented) was not untouched by the writer's inward-turned contradictions despite her choice of the variety of the narrative to intercept the strain of reminiscence (therefore the sentimentalism) of her poetry. "After being ill and suffering every form and variety of nightmare" (Letters IV, 231), Virginia Woolf "by the light of reason, tr[ies] to put into prose" (ibid) her idea of female empowerment to "keep entirely off" (ibid) the danger of patriarchy. Proving the efficiency of her feminist message as an author was within Woolf's battle against a stretched life of introversion with a view to explore the broader opportunity presented by prose. However, a conspicuous part of her mental instability was Woolf's unclear relation to the profit motif behind the project of female authorship which acquired a significance that always threatened to frustrate her very feminist concept.
\end{abstract}

Keywords-Feminism, gender-obsession, history, profit motive.

\section{INTRODUCTION}

Woolf's biography stands in a place where the line between androgyny and feminism can at times seem thin. While she bestows on Orlando the privilege of homoeros which enables him to infringe sexual stereotypes, transforming the bonds of gender-consciousness hardly leaves concealed Woolf's performativity of the idea of gender as what verges on double discourse. At first blush, androgyny saves the narrative from the obsession with gender thanks to the epiphany of the mother as the vehicle of an ecstatic state which is also synonymous with sexlessness. However, the unease we feel beneath the androgynous design of Orlando underscores the author's same oscillation between the introversion towards her biographical background (on the one hand) and the urge of extroversion typical of any aesthetic experience (on the other). A caboodle of other uncertainties furnishes Woolf's relation to whatever she exacts upon her ideal of the female writer. Nothing assures the defeat of this model. However, for all the optimism in the promise of toppling the monumental stereotyping of women as men's inferior, the female is bound with a life contract to a world system not easy to alter. I insist on the idea of contract in the sense of belonging to a pattern that exceeds gender divisions into a cosmic design that does not always take woman as its enemy. Changing perspectives is how a woman can be recognized as such. Besides, it is within Woolf's own discourse that the woman writer faces the haze of feminism: which actually denies her absolute victory. The a-clitic portrayal of Orlando is what spares him the vengefulness of a gender war. On the other hand, the empowered woman in $A R O O^{1}$ retains the same indecision when it comes to the parameters of her feminism. No matter what the bonds of a feminist commitment require, Woolf has created a situation in which a woman writer is unable to extirpate herself from an order equipped by her male counterpart as much as herself. So it is in nature, so it is in society: and with regards to feminism, changing the status quo for women begins with the unwillingness to relent to oppression rather than attempting to meet a condition that is not always corresponding to real life experience.

\footnotetext{
${ }^{1}$ All my subsequent mentions of A Room of One's Own will occur in the form of this abbreviation.
} 


\section{Introversion vs. extroversion: the uncertainty of Woolf between feminism and homoeros}

Woolf's starting point concerning women empowerment was the assertion of an equal right to education with men. However, it did not take long before her argument drifted into uncertainty. This is spotted in her excessive focus on the need for financial independency as the raison d'être to her entire struggle for women's rights. All this is reasonable enough. However, the feel of excess is instigated by the fervor of a gender-informed struggle which hides its other facet as the condescendence to the consumerist society set by a male-controlled world economy. Some critics, nevertheless, have seen quite the opposite. Here is Cliff Mills acquainting us with the subtle juncture between Woolf's demand for gender equality (on the one hand) and her ever-present recognition of the male design of a worldwide economist society (on the other):

She established the connections between a male-dominated world, a warlike world, and a world devoted to making money. Women, she argued, must "think back through our mothers" and assert their need for education, professional training, and a public life. (Cliff Mills 90-91)

One thing to notice, however, is that "a male-dominated world, a warlike world, and a world devoted to making money" together with a woman's "need for education, professional training, and a public life" (Mills 90) are in fact one and the same thing. I think I can locate the problem in the Woolf line of thought precisely in her indeterminacy when it comes to the issue of a woman writer having a public life. The truth is that a woman writer is not only in the public eye because she is interacting with people from both sexes but because she is part and parcel of an established world economy she is not really able to change. This reflection alone is capable of ensuring a good deal of controversy around the economic motive underlying the very call for women's liberation. In this sense, the feminist argument of Woolf risks to fall short of the overtness it meant for itself. Gabrielle McIntire is among the critics who found in the androgyny of Woolf's aesthetics a redeemer from many obsessions:

In a text that is more than half a flirtatious homage to the "reallife" Vita Sackville-West, Woolf draws analogies between herself and Orlando/Vita's mother, between birthing and writing a life, and between biological labor and the eros of the letter. In writing Orlando, Woolf claims to give birth to Orlando/Vita by writing his/her life as a fictional tale of androgyny across the centuries, loves her as her own child, and finds that in the eros of scripting her fictional-historical bios the alternately male and female biographer discovers a kind of Aristotelian happiness - where happiness is an activity expressing virtue, in this case the virtue of love. (McIntire, 119)

McIntire's remark is permeable to a considerable amount of skepticism. In a text much of whose length is a shout out to female writing as a metaphoric act of birth, one may justly ask: Why is Woolf in Orlando warding off genderconsciousness by conferring on Orlando an androgynous identity while she is also celebrating child labor as an exclusively female prerogative? Why didn't she (for example) replace child labor with the kind of metaphor inspired by the Hebraic or the Promethean myth of creation? Was she afraid of facing the charge of blasphemy? McIntire's reflection in the above quote is food for much thought as to the utility (also consistency) of Woolf's homoeros in a male-dominated world. That Woolf does not dispense entirely with the motherly instinct for the sake of homoeros is one way to doubt the very scope of McIntire's criticism.

In the above quote, McIntire visualizes the finality of the alternation of male and female consciousness as a form of Aristotelian happiness. One of the most pressing questions in this context is: How to pin down McIntire's idea of Aristotelian happiness in the first place? If McIntire is pointing to the Aristotelian happiness experienced by Orlando as the focus on the practical side of life rather than feelings, then this seems to be beside the psycho-behavioral depiction of Orlando who is in the midst of a criss-cross of feelings to say the least. From page 120 onwards, Woolf relates Orlando's unflinching sensitivity to female presence and absence at the same time:

"Sights disturbed him, like that of his mother, a very beautiful lady in green walking out to feed the peacocks with Twitchett, her maid, behind her; sights exalted him - the birds and the trees; and made him in 
love with death - the evening sky, the homing rooks" (12-13)

Orlando's solitary intimations are reported initially as something that "disturbed him". However, disturbance here is what only interferes with his field of vision. Once the fantasy begins, there is no hint of a nuisance befalling Orlando: contrary to that, his fantasized female presence has this capacity to transpose him into a state of ecstasy. One of the primary interests of this female apparition is this movement of the imagination to and fro between the two poles of presence and absence. By extension, we witness the same oscillation between genderconsciousness (on the one hand) and androgyny (on the other). My point is to say that imagination involves the broad significance of the gender of the apparition: namely femalehood. For all the exaltation it radiates, the same trance-like state is yet distinct for keeping the "dreamer" in love with death. It will be helpful, however, not to mistake death for an apocalyptic sense to life but to take it as the state of elation verging on non-being.

$\mathrm{We}$ are in for a rude awakening about the concomitance of female presence with death. This awakening is an additional layer to my current inquiry about the assurance (if any) brought about by Orlando's androgynous consciousness. Isn't the female (consciously or unconsciously) vying with androgyny over the literary space? In this case, why is the female always interfering with the neutrality of homoeros? Another thing: If the memory of the dead lady is a precursor to Orlando's gruesome fantasy, then it seems that homoeros in this equation is on par with death. Let me remind my reader that I conceive of death in my current analysis within a significance that vexes the idea of dying or of an ending to the life of a person, an organism or any other thing.

This considered, we need to cast a shaft of light on the idea of death also beyond the souci of any apocalypse to the aesthetic life of Orlando. Why again? It is because Orlando has been made by Woolf to resist incorporation within either of the two main gender patterns. This means that the presence of Orlando should not (and will not) be eclipsed by the gender of any other presence in his surroundings. Now how come that Orlando (who has been shielded by Woolf against sexuality) is made to be influenced by a female apparition? One may justly think that this pairing of the motherly apparition with death is Woolf's homage to the act of writing as conductive to a state of ecstasy. But this is valid only if we enclose the polysemy of death within the idea of ecstasy. It follows that motherhood breaks the narrow walls of its clichéd association with progeniture into the broader metaphor of artistic blooming. Androgyny is the grantor of this pairing of motherhood and death in an extroversion much in assonance with the author's self-claim about writing as procreative.

How actually anaclitical is Woolf's valence between artistic creation and androgyny in Orlando?: A biographic perspective

Another entrance into McIntire's analysis of Woolf's (a)sexual portrayal of Orlando can be found in the probable correspondence he finds between the epiphany of the ghost of the mother as instigating a reflection on death (on the one hand) and how (on the other hand) this probable correspondence feeds itself on some of Woolf's earlier life chapters where (a) she first lost her mother at the age of thirteen then (b) she declares to have felt an incestuous attraction to Vita Sackville-West. McIntire quotes Woolf's diary:

"lavishes on me the maternal protection which, for some reason, is what I have always most wished from everyone" (Woolf, 21 December 1925, Diary, vol. iii, 52).

"Protection" is the term used by Woolf to describe her own query during the connection she had with Sackville-West. Soon on the same page (i.e., on page 121), McIntire reverts to examining the point of view of Sackville-West about this very same connection. McIntire describes this relation as "anaclitic" (ibid) thus absolving it from any homoerotic suspicion. To flesh up his point, McIntire quotes SackvilleWest's own words from her letter to her husband, Harold Nicolson in 1926:

She makes me feel protective. Also she loves me, which flatters and pleases me... I am scared to death of arousing physical feelings in her, because of the madness. I don't know what effect it would have, you see: it is a fire with which I have no wish to play. I have too much real affection and respect for her.

While negating an erotic interpretation to Vita's point of view, McIntire quickly moves to accounting for the mechanism of narrativity in Orlando basically from the point of view of the narrator as three-layered:

a- First, there is Woolf who exists outside the text as its maker and de facto has lived a sexual experience with what will come through as the subject of her fiction. It seems in this sense that 
Woolf's narrative has this outer layer to it as a work of art destined for an audience worldwide (while it hides its other facet as an introvert kind of confession).

b- The narrator doubles when asking for his text to be read as autobiographically as fictionally. This metanarrative streak of the text adds to its uncertainty between introversion and extroversion.

c- The third layer to narrativity is when the fictional narrator (whom we still must distinguish from Woolf) is also affectively engaged with Orlando whom he androgynously bears as son, lover and historical subject (McIntire P 122).

What is remarkable is this arresting overlap between these levels of narrativity in Orlando: also consequently between the different personae embodied by Woolf to the point that they merge together when demarcation becomes too blurred between them. This merger becomes too obvious towards the end of "Mr. Bennett and Mrs Brown" when Woolf invites the reader to break the virtual divide between the writer and reader (Tidwell 74). However, the question persists: If the demarcation is so elusive then why is androgyny still obsessive at least in the Woolf literal discourse? This, in my opinion, is what makes the gender component as much obsessive as hard to capture. Paradoxically enough, Woolf's indulgence in androgyny reinforces genderawareness as the real subject of debate all the way through.

Orlando's feminized fantasy seems to disprove what Woolf had proclaimed in another place in the same book when she says: "Green in nature is one thing, green in literature another ... The shade of green Orlando now saw spoilt his rhyme and split his metre" (Orlando 13). Orlando's reverie is an enchanting experience though his "love with death" permeates many interpretations. I lean towards the interpretation of death as the brink of ecstasy because of its rather exalting quality for Orlando. Contrary to Woolf's self- proclamation in the quote above concerning the overlap between her quest for protection: natural and sensual (on the one hand) and the persona of the narrator in Orlando i.e., the literary or fictional side of her consciousness (on the other) is Woolf's major thought (on page 13) that physical nature has this disadvantage of always disconcerting the ways of literature. Woolf draws a line between nature and literature while also confessing to how her personal clitic drive impinges on the core of what she writes. This double discourse within the same text is the telltale about the not totally a-clitic relation of Woolf to her text or at least about her surrender to uncertainty when it comes to gender identity inside and outside her aesthetic experience.
This closure is also partly antithetical to McIntire's persisting thought about Woolf's own sexual inclinations (therefore about details from her biography if any) as determinant of the content of her literature. This thought by McIntire also gives the impression of a forcage, in my opinion, because it is the kind of thought which does not take into account the nuances made by Woolf herself. Part of the problem with McIntire is that she mistakes the biographical for the autobiographical thus also mixing the clitical with the aclitical without heeding the duality in the discourse of Woolf as what gives room for a plurality of interpretations.

Nena Skrbic has pointed out this diversity typical of the Woolf discourse beyond the merit of a polysemy. Skrbic diagnoses this polysemy essentially in terms of a crisis or friction which (in her opinion) splits the text into weaker units. Skbric leans on Woolf's account about the insufficiency of language to convey the immediacy of the charm emitted by colors. "Nature and letters seem to have a natural antipathy (Orlando 16). One thing to remember about Woolf is that she favors fiction more than any person's biography: thus also favoring literature above history. It seems that Skrbic departs from the literal meaning of Woolf's own string of words in Orlando to land on what she conceives as the insolubility of the rapport between colors (on the one hand) and the words in literature (on the other). "Beyond that was blue, pure blue, black blue; blue that had never filtered down; that had escaped registration" (Between the Acts 16). These are Skrbic's words about how undenotable" she finds Woolf's description of the color blue:

"The words "never filtered
down" and "escaped
registration" indicate that color
somehow escapes representation
and that words are too impure to
describe it." (Skrbic 52)

In keeping with her skeptical tone, Skrbic insists on a dissociation between the imprint of nature in Woolf's eyes (on the one hand) and the words emitted by Woolf (on the other). Her skeptical remark triggers the kind of unease that can be downsized by the promise that neither "nature" is outdoing "letters" nor the opposite. The endlessness of this dual between nature and letters is the kind of metaphor that builds up upon itself: thus always rising above the souci of a closure.

Rosemarie Buikema's thought about Woolf's genderconsciousness as historically-informed

In the course of her interpretation of $A$ Room of One's Own, Rosemarie Buikema quotes Woolf's idea that historians have been quite square in discarding the role of 
women in society. Buikema makes out that this act of exclusion is viewed by Woolf not only as a token of patriarchal oppression but also (and more alarmingly) as an established tradition. Another ensuing thought by Buikema is that this abuse against women is what made Virginia Woolf step into the world of fiction to ensure a new presence to the female (Buikema, 2). I will now pull a thread from the analysis woven by Buikema to arrive at the hypothesis that Woolf's aesthetic venture does not ultimately obfuscate male presence in favor of the female. This, in my opinion, corroborates my former comment on McIntire that gender is an elusive entity rather than systematically female-biased. Also, Buikema's commenting on Woolf's idea of gender as historyinformed (Buikema, 2) is my pretext for the current investigation in this subpart about the extent to which the position of the female in Woolf's fictional world is actually predicated on history:

"Women must explicitly situate themselves in the world through fiction, by using their imagination. This act of situating oneself does not merely concern catching up, supplementing a history that is largely unwritten, but also and especially so analysing the forces that structure that history." (Buikema 3)

Buikema maintains that the author's imagination is expedient to counterpoise male oppression. There is also the idea that this new privilege she would relish in the world of fiction has the merit of substituting for the broadly unwritten part of history. Fiction is therefore the grantor of female entrance (albeit virtual) into history. Noticeable, however, is the fact that Buikema begins her argument by announcing a double-layered crisis underlying Woolf's entire idea of history:

a- There is traditionally a deliberate obfuscation of female presence by male societal authorities which, in Buikema's opinion, transpires through art. Hence the observation made by Woolf "during her strolls in London" where she "sees a lot of monuments but they all refer to a history in which not a single woman is in sight." Buikema considers this remark made by Woolf highly symbolic but also very decisive. Buikema's account is somehow exaggerated because the maltreatment against the female is never so absolute. And yet we have to admit to a crisis which often ensues from the confrontation of the female with her patriarchal society. A woman "trespassing" on the outer rims of the enclosed space designed for her by her male counterpart is facing the charge of an infringement which invites punishment of some sort.

b- The second layer to this crisis (what Buikema also describes as "Woolf's second programmatic issue") is that this trespassing will happen only inside the world of fiction: that is "by [women ] using their imagination".

That it is not the kind of presence that enables women to "situate themselves in the world" unless through fiction is itself problematic. It testifies to a deep-seated awareness underlying the Woolf aesthetics about the actual impossibility of self-achievement for women: which generates this tendency to avenge women on the domineering male Other thanks to fiction. Not only that. Seeing women's revenge against the obfuscation exerted upon them in history in terms of a fictionalized existence (following the Woolf aesthetics) is a perspective which by perversely considering fiction as sine qua non for women empowerment and consequently for history-risks to forfeit efficiency by not strictly meeting the requirements of woman empowerment as a real life issue.

\section{The socio-economic stakes of a room of one's own}

An arresting instance of a paradox lies in the leitmotif of "a room of one's own": precisely in the idea of a woman who literally needs a room (that is an enclosed space) plus an income in order for her to be self-reliant. Why is fiction the standard promise of socio-economic advantage and not painting for example? This is among the uncertainties in the Woolf argument typical of the text of $A R O O$ which invites as much curiosity as discredit. Why? Because it betrays the sharp paradox between Woolf's initial claim in favor of fiction as a woman's haven from patriarchy (on the one hand) while it quickly reverts into a tribute to money as the very concretion of this selfaffirmation (on the other). A safe conclusion in my opinion would be that Woolf's ultimate goal was to turn literature into a source of material profit tout court and that anything beyond this conclusion is either a way for her to drift away attention from this truth or (on the other hand) an evidence about her inability to pin down her own literary venture to anything specific. In other words, she cannot help but swinging between the moralism of a not-for-profit life in fiction (on the one hand) and the vital need for a woman like for any human - to earn a living (on the other).

It seems that the discourse of feminism is inextricable from the gender divides within the economic tissue of a society. The female self is left with one of the two positions: either to be a financial burden to the oppressive male or to stand up for herself as a materially autonomous individual. However, in the last case, the female individual (who aims to challenge her extant material-cum-social disadvantages) will end up alienated 
from the very society she meant to challenge. It is simply because she cannot counter a system to which she concedes. This is the supreme uncertainty which threatens to undo the purportedly feminist message of AROO.

\section{Rethinking Woolf's idea of history: Woolf's argument in favor of character and against the Edwardians}

The consideration of the material side to Woolf's aesthetics provides one of the most arresting moments in her literature. We make sense of one of the paradoxes in the constitution of female authorship as what cannot be immune to the material influence of life (through the breaking of the news about Woolf's author acquiring a legacy from the colony) - but also explicitly to the colonial consciousness within Western authorship in its expulsion of ethnic subcategories. Ultimately, this legacy is as much material as colonial while it also demonstrates the intersection of history with the very celebration of this nascent female author. It is significant to begin by noticing how Woolf insists on discarding the hypothesis that the novel can be a colonial legacy:

"I believe that all novels, that is to say, deal with character, and that it is to express character-not to teach doctrines, sing songs, or celebrate the glories of the British Empire, that the form of the novel, so clumsy, verbose, and undramatic, so rich, elastic, and alive, has been evolved." (Woolf "Bennett" 9-10)

Joanne Campbell Tidwell has quite made a point in this connection: "Woolf denies the political aims of novels as valid goals" (Tidwell 72). Woolf claims that her art does not purport to teach lessons or to indoctrinate people especially about the nationalistic legacy of the British Empire. She even describes the genre of the novel as "undramatic" yet "rich" thus discarding from it the moralistic kind of obligation towards the political legacy of the British as a nation but also and mainly, as a history.

Woolf's aesthetics seems to be in dissonance with the monumental past of her nation precisely because this past (in the Woolf optic) is where the implementation of patriarchy has begun. Tidwell makes the remark that "Woolf does not deny the fact that the Edwardians are primarily concerned with character, but she argues that "they are concerned not with the spirit but with the body" ("Modern Fiction" 147). Here is Tidwell explaining this thought:

"Mr. Bennett and Mrs. Brown" appeared in the New York Evening Post in 1923 and was repeatedly reprinted. In both essays, Woolf describes two groups of writers, the Edwardians and the Georgians. In the Edwardian camp she groups H.G. Wells, John Galsworthy, and Arnold Bennett. On the Georgian side are E.M. Forster, T.S. Eliot, James Joyce, and presumably Woolf herself. The Georgians are later called the modernists. The Edwardians might be best described as post-Victorian or pre-modern writers." (ibid)

We understand from the argument laid forth by Tidwell that Woolf has made the kind of taxonomy separating the Edwardians from the Georgians while claiming her own style to be specifically "Georgian". She justifies her selfclassification as a modernist in terms of the adversity she bears against the patriarchal legacy.

In my opinion, this new idea of history postulated by Woolf ends up frustrating the writer's credibility. The disorder stemming from the equation she fails to strike between fiction (on the one hand) and materialism (on the other) is what also disorients her so-called modernist perspective of history. In other words: How can we possibly take in Woolf's thought that her art is exclusive to character and not to "teach[ing] a doctrine" or to "sing[ing] a song" while in AROO, for example, she claims that an income is needed for a woman to survive in a patriarchal world. It follows that the woman character is fully committed to singing the song of her society. Another question: How can Woolf claim to focus on character as soul while she is actually concerned with character as body, gender and money. She argues against the Edwardians by saying that "they are concerned not with the spirit but with the body" ("Modern" 147) -while she is actually concerned with corporea materia when it comes to the characters she creates. Here is Tidwell again:

\section{"Woolf illustrates this beautifully in "Mr. Bennett and Mrs. Brown" when she describes a scene on a train, using both her own Georgian style and a slightly tongue-in-cheek version of the Edwardian style. The Edwardian details may tell us where the character is traveling but not why. They may tell us that she is poor but not why she is proud" (Tidwell 72)}

Tidwell's words invite my pressing inquiry about the extent to which we can extricate the character from its world: precisely its patriarchal past: i.e., the extent of the character's dissonance with his society. Now let us recall Woolf's own words:

“[Bennett's] characters live abundantly, even unexpectedly, but it remains to ask how do they live, and what do they live for?" ("Modern Fiction" 148) 
On page 72, Tidwell quotes Woolf's labeling of the Edwardians as materialists:

"If we fasten, then, one label on all these books, on which is one word materialists, we mean by it that they write of unimportant things; that they spend immense skill and immense industry making the trivial and the transitory appear the true and enduring" ("Modern" 148).

It seems that the alleged power in the Woolf rhetoric against the Edwardians finds its way into prominence only while maintaining the substantive materialists as a charge that (ironically) applies to Woolf's literature in more than one way as I have explained. The anti-colonial associations developed in Woolf's aesthetics of character hardly depart from a stigmatization of the Edwardians: it also betrays more than one instance of self-contradiction.

Tidwell accounts for Woolf's venture of revolutionizing literature using a modern approach to history (Tidwell, 73). Woolf makes it clear that change begins with the position of women in the family then in society and consequently in politics. She considers the same progression for the representation of the female in literature:

"All human relations have shifted-those
between masters and servants, husbands
and wives, parents and children. And
when human relations change there is at
the same time a change in religion,
conduct, politics, and literature."
("Bennett" 5)

Woolf's project within modern aesthetics is to dissipate the inherited masculinization of the literary tradition: especially of the period of the Edwardians. Tidwell unarguably adopts Woolf's standpoint about history as a repository of dogmas. He yet does not pause to reflect on the excess suffusing Woolf's standpoint in this regard:

"Old methods of writing about society and human relationships no longer work. Writers must revolutionize writing, especially characterization. Here, politics have affected literature. Aesthetics have adjusted because of political alterations. Earlier, Woolf wrote that the novel's purpose was not political, but here she demonstrates that writing is not separate from political issues. The Edwardians' materialist methodology is no longer effective because values have changed." (Tidwell 73)
It seems that the same excess has been transposed to the Tidwell account where he fails to designate the common flaw between Woolf and the Edwardians. Part of this commonality is that Woolf's celebration of the female individual is not at odds with her materialism. This is what Tidwell misses in the analysis he makes in furtherance of the diary:

"In her fiction, Woolf attempted to alter that structure, sometimes slowing time and at other points speeding it up, as in To the Lighthouse, in order to mimic the cadence of real life. In her diary, however, she follows the tempo of life by default. Instead of imposing an external order on life, as fiction does, the diary allows life to order the literature, [...] to use the domestic as a guiding force in [her] art." (Tidwell 82)

Fiction coalesces with reality within Tidwell's view about the genre of the diary. However, he does not clearly respond to Woolf's argument against the Edwardians. Even when he reverts to questioning the very artistry of the diary, Tidwell does not revisit Woolf's materialism when it comes to the latter's idea of character:

"Is the diary art, or is it merely a useful place to write out the fidgets, as she sometimes claims? Does the diary record real life, or is Woolf playing with reality? Her home life and her creative life are inevitably mixed together in the diary [...]" (Tidwell 83)

Tidwell makes a historical point about Charleston as a haven for Reed (as for Vanessa Bell) to turn to from the hazards of WWI. The emblematic effect of this setting (what Tidwell on page 82 refers to as pacifism) enables us to visualize some of the obsessions underlying Woolf's preference for the genre of the diary as a stand against (what she views as) the Edwardians' materialistic concern with character. And yet, the permanent symbolism of the setting in the Woolf literature brings us face to face with the author's deep-seated historical-consciousness which cannot help infiltrating her diary. It ends up that the diary takes more from the genre of the biography than from fiction: it is closer to the historical timeline of Woolf and her contemporaries. In light of this, I think it is safe to arrive at Woolf's historical materialism as what filigrees her text: a truth she probably was too arrogant to condescend to taking upon herself. 


\section{The (cultural) stakes of the profit motive in Woolf's engagement with market economy}

In AROO and the Three Guineas, Woolf makes a point by saying that a woman can take writing as a livelihood. In her book, Gifts Markets and Economies of Desire in Virginia Woolf, Kathryn Simpson reflects on the dilemma concomitant with this woman-empowering venture. Simpson criticizes this aesthetic-cum-professional venture as the place where "women run the risk of being seduced and subsumed by the powerfully enforced ideologies and values of the male-dominated capitalist system, and of being entrapped anew by the pressures of the profit motive" (Simpson 14). Simpson is assuming that Woolf is undergoing (or at least running the risk of) a dilemma. In other words, she hypothesizes that Woolf is trapped in the uncertainty (what Simpson on page 14 refers to as anxiety) between the vital need for financial independency (on the one hand) and the societal repercussions of the fulfillment of this need (on the other). Being paid as a writing professional is, according to Woolf in AROO, what saves the literary profession from the humility and frivolousness accompanying a writing that is left unpaid: Paying a female writer, says Woolf, "dignifies what is frivolous if unpaid for" (AROO 62).

Beyond the self-assured tone of Woolf about the essay as a staple of modern literature, she remains unsure about the rapport between her art and how mass consumerism can affect the quality of the essay as much as the feedback it will receive. Woolf remains reproachful towards market economy with regards to the impending danger presented by mass consumers vis-à-vis her art. She justly thinks that her audience may intervene with the quality of what she writes because (as the producer in the chain of consumerism within market economy) she has an audience to please whether she likes it or not. This, in itself, is food for much discomfort on her part no matter how she seems to admit to playing the game of market economy. Reaching the status of the woman writer (who is ipso facto financially independent) paradoxically cannot spare this same woman the trouble of having to deal with the financially ensnaring consumerist society (Kathryn Simpson 14).

Portraying herself as a shopper is one of Woolf's techniques of how to spotlight the female response to the patriarchal dominion: here from the perspective of market economy. AROO aptly engages the female in "the everchanging and turning world of gloves and shoes and stuffs" (AROO 86). This depiction alone is capable also of positioning the female within the inexorable tide of fashion and consequently of time. Beyond the concern for clothing items, the female shopper in $A R O O$ has a double prerogative. She is object (bound to follow fashion as a consumer) and also subject (actively committed to promoting the market economy by means of her purchasing power). We make sense of the female position in the modern world through the expedient of fashion and of shopping. Here is Kathryn Simpson again:

"Although Woolf depicts herself often as
a somewhat reluctant shopper, her
writing asserts the importance of
women's economic freedom and
participation in this central experience of
modernity" (Simpson 15).

I may adduce that the instance of the reluctant shopper is a metaphoric hint about whether to admit her contribution to the market economy as a tangible proof of her independence from the custody of the masculine or (contrary to that) to take this very contribution as a reinforcement of her subjugation to a world economy all designed by men: therefore as a reinforcement of her historically-unchanging position as man's second.

Few lines down, Kathryn Simpson treats this very same hypothesis: that is whether to take the female shopper as the embodiment of free will or not:

"As shoppers, women are subject to the
manipulative power of a male dominated
capitalist economy driven only by the
profit motive, which sets up a power
dynamic in which women are
constructed as passive dupes, tricked into
spending money on the basis of an
impossible promise of a satisfaction of
desires." (Simpson 14-15)

An arresting irony lies in how Simpson arrives at the more disconcerting truth that women's desires are never fully satisfied in the market economy. This truth (that women shoppers are forever thwarted by the impossibility for their wishes and desires to be fulfilled) yields the more bitter certainty that capitalist economy is the carrier of the cliché about men as dallying in love matters: therefore as the potential manipulators of women. Rather than adjusting to our expectations about the benefits of female engagement in market economy, the capitalist context of AROO acquaints us with a new portrait of the female in a constant tug-of-war against a male world order. Participating to capitalist economy as a writer (then ipso facto as a consumer) brings the female face to face with the truth that (in so doing) she is unconsciously asserting her passivity in a men's world. By earning a living from writing, a woman is paradoxically repositioning herself in the midst of an economy where she seems to have no rights to waive in the first place. The profit motive transcends the market 
economy and is consistent with women's larger gender struggle. The latter comes through essentially as a battle for survival rather than a control issue.

In Mrs Dalloway Woolf makes the precision that taking care of a dog is of higher importance "than sitting mewed in a stuffy bedroom with a prayer book!" (Collected Novels 41) By ridiculing the reading of a book of prayer in terms of the passivity it entails upon the minds of its readers, Woolf attempts to rectify this status quo through writing. Woolf's bias for writing reveals itself as a reactionary response to reading as what she construes as mere imbibing of old precepts and dogmas. Besides, old literature is written by males usually with "fantastic Christian names" (Collected Novels, 5): it basically records their past victories in wartimes more than anything else. However, and for all its luring associations, the historical hypothesis made by Woolf hardly spares her the trouble of self-contradiction. How? This is simply by acknowledging the merit of writing over reading. It is as if she is unconsciously immunizing her body of literature against male readership in a metaphoric act of sexual priggishness (what the French call pudeur). So, on the one hand, Woolf preaches writing as a livelihood for the female seeking empowerment. On the other, Woolf resists old texts whose readership is plagued by the mania for religious and historical glories. So, how can she be against the act of reading (if only of old prayer books) while she also needs a readership for her written material (otherwise she will technically not earn a penny)? This ambivalent attitude is what in my opinion creates this feel of anxiety in the mind of Woolf as in my own. Woolf's persisting discomfort with a literary corpus she deems monumental (because it is either written by males or targeting the lazy minds of a religious audience) already betrays the obsessive character of gender in her mind. A similar remark has been sustained by Kathryn Simpson that anxiety "[is] also a product of Woolf's largely antithetical attitude to consumer culture" (Simpson 14). A possible solution to this riddle can be sought in the Woolf's admittance of the inherently fragmented nature of modernism and that it ultimately finds meaning to itself in the eclectic aspect of its readership.

Woolf's unease about the question of gender in modernism has also been highlighted by Elena Gualtieri who brings into contact the two poles of Woolf's dilemma: namely "cherish(ing) the essay as the first of modernist forms in its fragmentary, unresolved and preliminary character" (Gualtieri 18) (on the one hand) and "[Woolf"s] perception of the modernity of the genre, which she saw as indissolubly linked to the emergence of mass readership, consumer culture" (ibid) (on the other).

\section{The uncertain substitutability of Woolf's grievance against science}

Woolf states that the worth of her aesthetics will be shown as what gives women a chance to substitute for the adversarial position they were made to occupy not only in literature. In the Woolf logic, literature can be oriented towards redeeming the deliberate eschewing of women in different walks of life: science, genetics, neurology, to name only a few:

"Throughout A Room of One's Own, Woolf remains mindful of science as part of culture, both as a part of culture which has oppressed women, and as a part to which they have contributed and can continue to contribute" (Michael Whitworth 176)

This is the remark made by Michael Whitworth about Woolf's message in AROO which compresses her criticism of the reductionism typical of $19^{\text {th }}$ century science and culture at large. If it were not the case, Woolf points out, "the subject of our talk might have been archaeology, botany, anthropology, physics, the nature of the atom, mathematics, astronomy, relativity, geography" (AROO, 27). Woolf hits a fair point with her self-account that her literature is the mirror-image of a state of crisis entailed by the absence of the female from the intellectually-engaging field of science. Beginning by admitting to an extant crisis is Woolf's preliminary towards offering a solution to the slot in the cultural landscape left by the exclusion of women.

However, the pessimism accompanying this very admittance hardly takes her argument anywhere beyond a frenzied incrimination with no apparent possibility of redemption. Woolf's ironic remark in the same direction (for its tongue-in-cheek aspect) corroborates this same idea: "take an apple and remark, Newton discovered the laws of gravitation and Newton was a woman" (AROO 111). Woolf's concern is double: it is one of social status which automatically migrates into a souci about the literary canon. However, by claiming this crisis, she is also unconsciously acknowledging the merit of science over literature: as if a woman scientist is a priori superior to a woman of literature. By extension, Woolf seems to have an inferiority complex or at least to be not fully cloyed with literature as a woman-empowering profession let alone as an intellectual activity.

Providing an argument which bears riddles as to her own complacency about the feminist cause leaves unconcealed the deep-seated crisis in the Woolf argument. She postulates that, because women are excluded from science, then they stand no chance to embody a scientific 
profile in literature. Woolf's concern with the oppression exerted upon women is unconsciously transformed into an exacerbation of the same injustice. Woolf is de facto translocating this extant crisis from reality into her literature by taking science as a vintage point. Woolf has designed her literature as a surrogate for science. However, this design casts down women's entire fortune to catch in literature. Even though Woolf's feminist purpose is elevating, what partly invalidates it is this reference to science as the requirement for its solemnization.

\section{Berating Whitworth's optimism about the vitality of Woolf's message}

This subpart is arranged as a reactionary response to the claim made by Michael Whitworth about vitality as what he considers to be Woolf's most distinctive purpose in $A R O O$ but also as the connecting thread between the socio-economic background of the author (on the one hand) and the book itself (on the other). Here are Whitworth's words:

"The crucial concept for A Room of One's Own is vitality. Vitality is the conceptual bridge between the material conditions for literary creation (money and privacy) and the act of creation itself." (Whitworth 176-77)

In effect, glossing Woolf as "mindful" (Whitworth 176) of the status quo is self-contradictory. In the Whitworth logic, Woolf is mindful of women's oppression in the patriarchal society. On the other hand, Whitworth finds in this mindfulness a vitalizing force (he uses the substantive vitality) which -according to him-connects the book to its socio-economic background in very positive terms. In my opinion, this can be true only if the book offers tangible solutions to women's oppression.

Another problem with Whitworth's use of the epithet mindful is its striking neutrality at least in this context. I think this term fails to confer any edge on Whitworth's criticism of the conceptual (as well as the constructive) purpose of $A R O O$. Rather than answering the question How does $A R O O$ ever intervene to mend the ills of society? - Whitworth has stopped at a diagnosis of the problem and that is it.

I validate the same remark for Whitworth's use of the term vitality. Vitality is what Whitworth conceives as the umbilical cord connecting the "material conditions" surrounding the appearance of the book to the latter as a literary output. Let us agree that the term vitality is somewhat vague if not downright nonsensical. Although the term attempts to account for the energy emitted by $A R O O$ (from the Whitworth perspective) as something positive, uplifting and even buoyant, I think that it ultimately casts a meager quality on his interpretation of the novel for not just one reason.

Taken from the side of logic alone, this account occurs within the chapter entitled "Scientific and Medical Contexts". This chapter exposes different prejudices about women's inferiority in terms of mental health that have been reinforced within the medical context since the $19^{\text {th }}$ century and even before. Energy is a key-concept in this chapter which treats the evolution of medical treatment of cases of neurasthenia from both genders and how this medical treatment was deeply influenced by the $19^{\text {th }}$ century medical theory which, in turn, reverberates with the popular theories of thermodynamics of the same period. According to these theories, a woman's provision of energy should be kept aside for the sake of reproduction; while a man is allowed to be more physically engaged in his daily practices because he is thought to have a more active disposition: "Male cells had the tendency to dissipate energy, while female cells stored or built it up" (Whitworth 171-72). What arrests me is that Whitworth's account about "the 'active' qualities of sperm and the 'passive' qualities of ova" (ibid) remains neutral all the way; therefore on the expository (rather than the argumentative) side. I would say that the affirmative form in which it occurs condemns Whitworth's entire statement (at least in my opinion) to complicity.

In this case, how can we ever adhere to his former description of a so-called vitality animating the textcontext relationship in $A R O O$ ?

If "the conceptual bridge" (Whitworth 177) between Woolf's text (on the one hand) and the historical influence behind it (on the other) is not brought under a lens which seeks to criticize then to mend this very bridge, then the vitality of this conceptual bridge observed by Whitworth vibrates with nothing but the mimesis of a persisting state of crisis. In other words, unless we consider the social images depicted in Woolf's work as ironic, then Whitworth's notion of vitality applies only to an expanding old life system according to which women are kept as men's second. Vitality, following Whitworth's logic, can be tracked down in the survival of the old system which finds legitimacy to itself in the survival of gender divides in social behavior as well as in science. This is a good justification if we want to adopt Whitworth's idea of vitality in the bond between text and society. As a result, if the role of the novel stops at recording gender-conscious distinctions, then it (i.e., the novel) will hardly upgrade itself beyond the level of a diary. The charge of complicity, then, is contaminating the novelist who, herself, embodies the figure of the condescending, will-less (never the embattled) female. By 
this same logic, the substantive creation used by Whitworth will remain on the allusive side because we cannot speak of an act of literary creation in the case of Woolf as long as no hammer is wielded in the face of old gender dogmas. In other words, there can be no cohabitation between a text that is vitally connected to its dogmatic socio-economic entourage (on the one hand) and the prospect of a literary creation (on the other). If one exists, the other will vanish.

\section{CONCLUSION}

The impermanence of Woolf's skepticism about the men-made capitalist society is a problem that her feminist message hardly seems to solve. By binding the history of her nation also to a celebration of men's achievements (basically conquests), Woolf is also falling into self-contradiction when dodging the nationalistic past of her country wholesale. Her emphasis on character as what should exceed the intramarginal (sexual and materialistic) depiction of women and make allowance (in her logic) for the more enlivening dramatic commitment is also wanting in its relation to the stakes of the now-point of the present. Paying nothing to whoever sings the songs of its society is how Woolf scoffs at the conformism with a history made to worship its male idols. However, and for all the pessimism she seems to bear to the idea of history, Woolf is also depicting the woman in full commitment to the now through the medium of fashion. The metaphor of a woman in a store shopping for shoes and gloves is the perfect telltale of adaptation to the flow of history. Woolf, anxious to win honor against her patriarchal society, is unwittingly falling for the very system she has planned to debunk. Fashion is one of the conditions of women's contract to the profit motive. Woolf's argument is not infrequently out of joint. She fails to color her point of view to the truth about women's being part and parcel of the mercantile society where she can live out no full independence unless she exposes her literature to an audience from both sexes and consequently gets paid from both. Woolf's anxiety is not less sharp in her approach towards science. She finds in the unjust avoidance of women's presence in science much of a springboard to raise the same issue in literature. However, she betrays her deeper thought that her aesthetic orientation is a matter of expediency rather than a choice based purely on a feminist cause. Ultimately, it is not without meaning that Woolf's gender-conscious distinctions are motivated by a keen discontent about a historical condition that is never offset by the desire to score victory over men. In attempting to understand Woolf's argument as an ode to female independency, we succumb to the more realistic closure that feminist authorial control is about committing oneself to a position of an utterly metaphysical quality.

\section{REFERENCES}

[1] Buikema, Rosemarie. "Virginia Woolf's Postcolonial Feminism". Position Paper for 'Terra Critica: Re-visioning the Critical Task of the Humanities in a Globalized World', December 7/8, 2012, Utrecht University. Web.

[2] Gualtieri, Elena. Virginia Woolf's Essays: Sketching the Past. Basingstoke and London: Macmillan, 2000.

[3] McNichol, Stella, ed. Collected Noels of Virginia Woolf: Mrs Dalloway, To the Lighthouse, The Waves. London: Macmillan, 1992.

[4] Mills, Cliff. Virginia Woolf. Introd, Congresswoman Betty McCollum. Philadelphia: Chelsea House Publishers, 2004.

[5] Nicolson, Nigel (ed). Vita and Harold: The Letters of Vita Sackville-West and Harold Nicolson. New York: Putnam, 1992.

[6] Simpson, Kathryn. Gifts Markets and Economies of Desire in Virginia Woolf. London: Palgrave Macmillan, 2009.

[7] Tidwell, Joanne Campbell. Politics and Aesthetics in the Diary of Virginia Woolf. Ed, William E. Cain. Routledge: New York, 2008.

[8] Whitworth H, Michael. Virginia Woolf. New York: OUP, 2005.

[9] Woolf, Virginia. "Modern Fiction." The Common Reader, First Series. Ed. Andrew McNeillie. New York: Harcourt Brace, 1925.

[10] ------------.-. "Mr. Bennett and Mrs. Brown." The Essays of Virginia Woolf, Vol. 3, 1919- 1924. Ed. Andrew McNeillie. New York: Harcourt Brace, 1991.

[11] ----------.. A Room of One's Own. London: Hogarth Press, 1929. Harmonds worth: Penguin, 1992.

[12] -----------.- Between the Acts. Ed. Gillian Beer. Harmondsworth: Penguin, 1992.

[13] -----------. Orlando: A Biography, 1928. Ed. Brenda Lyons, Introduction and notes by Sandra M. Gilbert. New York: Penguin, 1993.

[14] ------------. The Diary of Virginia Woolf, 5 vols. Ed. Anne Olivier Bell. New York: Harcourt, 1980.

[15] ----------. The Letters of Virginia Woolf. 6 vols. Ed. Nigel Nicolson and Joanne Trautmann. London: Hogarth Press, 1975-1980. 